\title{
Processing of South African biltong - A review
}

\author{
M. Jones ${ }^{1,2}$, E. Arnaud ${ }^{2,3}$, P. Gouws ${ }^{1}$ \& L.C. Hoffman ${ }^{2 \#}$ \\ ${ }^{1}$ Department of Food Science, University of Stellenbosch, Private Bag X1, Matieland (Stellenbosch) 7602, South Africa \\ ${ }^{2}$ Department of Animal Sciences, University of Stellenbosch, Private Bag X1, Matieland (Stellenbosch) 7602, South \\ Africa \\ ${ }^{3}$ CIRAD, UMR QualiSud, F-34398, Montpellier, France
}

(Received 29 June 2017; Accepted 18 August 2017; First published online 16 September 2017)

\author{
Copyright resides with the authors in terms of the Creative Commons Attribution 4.0 South African License. \\ See: http://creativecommons.org/licenses/by/4.0/za \\ Condition of use: The user may copy, distribute, transmit and adapt the work, but must recognize the authors and the South African \\ Journal of Animal Science.
}

\begin{abstract}
South Africa has been producing biltong for many years and its popularity is increasing locally and internationally. Biltong is commonly grouped with other dried meat products from around the world, but with its unique production method and expanding economic value, an increase in knowledge on the subject is in high demand. In this paper, biltong processing and quality are reviewed to highlight areas in which knowledge is still lacking. It shows that biltong processing varies resulting in the wide physico-chemical characteristics reported in the literature. However, consumer preference is still an area that lacks scientific data/evidence. Previous research on biltong has focused on the pathogenic microorganisms and not on its spoilage and shelf-life. Moreover, the effects of the various processing methods on the physico-chemical characteristics and resulting microbial stability has not been investigated. Knowledge of these could enable an increase in the quality of biltong.
\end{abstract}

Keywords: Drying, meat product, microbiology, physico-chemical, salting, shelf-life

\#Corresponding author: Ich@sun.ac.za

\section{Introduction}

The production of biltong, a popular ready-to-eat salted and dried meat product from South Africa, involves a series of steps, including meat preparation, salting, spicing and drying. The preservation of meat through curing and drying is not a new concept. Centuries ago, seafarers salted and pickled meat in wooden barrels so they had food during the long months at sea. It has been said that the indigenous tribes of Africa had their own methods for meat preservation before the first settlers came to Southern Africa. These involved salting and drying meat. Once on land, the first settlers allegedly adopted this process, because of the need for food preservation. While game (wild animals/ungulates) was abundant in Southern Africa, they had no means of storing the meat that was hunted. They took to drying it in the sun like the indigenous tribes, but added vinegar and spices. The spices they used, which are still the same (see below) were abundant from the then Cape Colony and the vinegars were made from the grapes of the French Huguenots. So drying became an accepted means of meat preservation. The Voortrekkers (early pioneers) cured and dried the meat for up to two weeks and wrapped it in cloth for transportation before setting out on their travels across the continent (Coetzee, 1977). The word 'biltong' is derived from the Dutch word 'bil' meaning round or buttock, and 'tong', which is related to tongue, because biltong is made from strips of meat (Strydom \& Zondagh, 2014).

Nowadays, biltong is produced on a small scale (households, butcheries) and larger scale (industry) using several recipes and processes to accommodate demand (Strydom \& Zondagh, 2014). Many countries have a speciality dried meat product. Beef jerky (North America), charqui, carne seca and carne do sol (South America) are most frequently compared with biltong, for example in the studies of Dzimba et al.(2007), Matsheka et al. (2010), Mhlambi et al. (2010) and Petit et al. (2014).

This review gives an overview of general and scientific knowledge about biltong processing, its characteristics, consumer trends and the biltong market. Critically evaluating the literature on hand, this review allows for an understanding of the gaps in research that must be filled to increase the quality of biltong for the local market and exportation. The factors that influence the quality of the final product, the microbiology, and shelf-life of biltong are discussed. 


\section{Dried meat products}

Various countries produce dried meat products. Table 1 shows the most popular dried meat products from ruminant animals that are described in the scientific literature (Leistner, 1987; Hui, 2012; Toldrá, 2015; Pintado et al., 2016) and on websites.

Biltong is similar in its shape to the products made from meat strips (not made as a whole muscle) that are listed in Table 1, but it differs from them as it is ready to eat, meaning it is eaten as a raw product with no preparation (such as rehydration, desalting and cooking) being required before consumption. Brazilian charqui for example has high salt content (12-15\%), and is desalted before consumption (Santchurn et al., 2012). Jerky is most commonly compared with biltong, but it is dried at higher temperatures (Burnham et al., 2008), for example at $60^{\circ} \mathrm{C}$ (Carr et al., 1997), therefore the process and the end product differ from biltong. Another unique attribute of biltong is that on many occasions vinegar is used in the salting step. This is not seen in any of the other products in Table 1.

Table 1 Dried meat products from ruminant animals from selected countries

\begin{tabular}{|c|c|c|c|}
\hline Dried meat product & Country of origin & Description & Meat used \\
\hline Biltong & South Africa & Salted, dried meat strips & Beef or game \\
\hline $\begin{array}{l}\text { Bündnerfleisch/ } \\
\text { Bindenfleisch/ } \\
\text { Grisons meat }\end{array}$ & Switzerland & Salted, dried meat 'deli-style' & Beef \\
\hline Borts & Mongolia & $\begin{array}{l}\text { Dried meat strips, often ground into } \\
\text { powder }\end{array}$ & Horse or beef \\
\hline Bresaola & Northern Italy & Salted, dried meat 'deli-style' & Beef \\
\hline Bògoq & Northern Canada & Dried, smoked meat & Often caribou \\
\hline Carne-de-sol & Brazil & Salted, dried meat strips & Usually beef \\
\hline Carne seca & Mexico & Salted, dried meat & Beef \\
\hline Cecina & $\begin{array}{l}\text { Cuba, Mexico, north } \\
\text { western Spain }\end{array}$ & $\begin{array}{l}\text { Salted, dried, lightly smoked } \\
\text { meat strips }\end{array}$ & $\begin{array}{l}\text { Spain: Beef or horse } \\
\text { Mexico: Beef or pork }\end{array}$ \\
\hline Charque/Charqui & South America & Salted, dried meat strips & $\begin{array}{l}\text { Llama or alpaca } \\
\text { Beef or horse }\end{array}$ \\
\hline Droëwors & South Africa & Salted, dried sausage & Beef or game \\
\hline Fenalår & Norway & Salted, dried meat 'deli-style' & Sheep \\
\hline Jerky & North America & $\begin{array}{l}\text { Salted, dried meat strips, sometimes } \\
\text { smoked }\end{array}$ & Usually beef \\
\hline Kaddid/Qadid & $\begin{array}{l}\text { Northern Afghanistan, } \\
\text { Northern Africa, Pakistan }\end{array}$ & Salted, dried meat strips & Often lamb \\
\hline Kilishi & Sahel Africa & Dried, roasted strips of meat & Beef, sheep or goat \\
\hline Kitoza & Madagascar & $\begin{array}{l}\text { Salted, dried meat strips, sometimes } \\
\text { smoked }\end{array}$ & Beef or pork \\
\hline Kuivaliha/Kapaliha & Northern Finland & Salted, dried meat strips & Often reindeer \\
\hline Mipku & Northern Canada & Dried strips of meat & Caribou or reindeer \\
\hline Nikku & Canadian Artic & Dried strips of meat & Caribou \\
\hline Pastirma & Armenia, Egypt, Turkey & Salted, dried meat 'deli-style' & Beef \\
\hline Pemmican & North America & $\begin{array}{l}\text { Dried meat strips-fat mixture, } \\
\text { sometimes with added dried fruit, } \\
\text { pounded into powder }\end{array}$ & $\begin{array}{l}\text { Large game: buffalo, } \\
\text { moose, elk or deer }\end{array}$ \\
\hline Sucuk & Turkey & Salted, dried, fermented sausage & Beef or buffalo \\
\hline Suhomeso & Bosnia & Salted, dried, smoked meat strips & Beef \\
\hline Sukuti & Nepal & Salted, dried meat strips & Lamb \\
\hline Taicang & China & Dried, shredded meat & Pork or beef \\
\hline Tasajo & Cuba & Salted, dried meat strips & Beef or horse \\
\hline
\end{tabular}

'Deli-style': meat produced from whole muscles 


\section{Biltong physico-chemical characteristics}

The final physico-chemical composition of biltong is important as it influences the sensory properties of the products and is an indication of a shelf-stable product. Factors to consider for the final composition of biltong are the moisture and salt content, the water activity $\left(\mathrm{a}_{\mathrm{w}}\right)$, and $\mathrm{pH}$.

There is no legal definition of biltong, unlike charqui, which, according to Brazilian legislation, should contain $40-50 \%$ moisture and $10-20 \%$ salt (Brasil, cited by Lara et al., 2003). The derivative meat product, jerked beef, is also officially defined by the Brazilian legislation as having maximum $55 \%$ moisture, $50 \mathrm{ppm}$ sodium nitrite, $18.3 \%$ ash, a final $a_{w}$ value of 0.78 and being vacuum packed (Brasil, cited by Pinto et al., 2002). The United States Department of Agriculture (USDA, 2014) guideline suggests a maximum $a_{w}$ of 0.85 for jerky.

Biltong can be produced using recipes with various amounts of salt and can be more or less dried, as reflected by the wide range of characteristics reported in the literature. Scientific studies on the physicochemical characteristics of commercial biltong are mostly from the 1970s-1980s (Van den Heever, 1970; Van der Riet, 1976a; Osterhoff \& Leistner, 1984), except for the recent study of Petit et al. (2014), which was conducted on 11 samples. Moisture content was reported to range between 10 and $50 \%$ with $\mathrm{a}_{\mathrm{w}}$ between 0.54 and 0.89, with one sample being reported at 0.93 (Van der Riet, 1976a; Osterhoff \& Leistner, 1984; Petit et al., 2014). Many reports refer to moist and dry biltong (Nortje et al., 2005; Dzimba et al., 2007; Mhlambi et al., 2010; Petit et al., 2014), but there is no evidence of the values of moisture content or $a_{w}$ that classify biltong as 'moist' or 'dry'. In the 1970s, the commercial industry believed the moisture content should be $30 \%$ or more, while a moisture content of $20-30 \%$ was reported to be ideal in the 1940s (Van den Heever, 1970). Nortje et al. (2005) defined moist biltong as having a moisture content higher than $40 \%$ and, from the data on commercial products in the literature at this time, having an $\mathrm{a}_{\mathrm{w}}$ range between 0.84 and 0.93 (Van der Riet, 1976a; Osterhoff \& Leistner, 1984). Petit et al. (2014) distinguished two groups of biltong: those with a moisture content between 21.5 and $25.3 \%$ and $a_{w}$ between 0.65 and 0.68 , which they classified as 'dry', and those with a moisture content between $35.1-42.8 \%$ and $a_{w}$ between 0.85 and 0.89 , which they classified as 'moist'. It is evident that the higher the moisture content, the shorter the potential shelf-life, but the higher the yield per unit and the higher the profit. Salt is the main spice used in the production of biltong and is considered a 'curing agent'. The final salt content of biltong varies, depending on the amount of salt used initially, and the level of drying because salt concentration increases due to the reduction in moisture. Salt content can range from 2 to $11 \%$ but, most biltong usually having a final salt content of $4-8 \%$ (Van der Riet, 1976a; Osterhoff \& Leistner, 1984; Petit et al., 2014). The pH of biltong mostly ranges between 4.8 and 5.9 (Van der Riet, 1976a; Osterhoff \& Leistner, 1984; Petit et al., 2014). This pH is influenced by the type of meat (beef, game, or ostrich) and the stress the animal experienced ante mortem. The final $\mathrm{pH}$ of biltong can also be influenced by the addition of an acid in the salting/spicing step. The low $\mathrm{pH}$ values of some biltong (4.8-5.0) that were reported in previous studies (Osterhoff \& Leistner, 1984; Petit et al., 2014) could be due to vinegar addition, but no information about their processing methods is available to verify this.

Biltong is considered an intermediate-moisture food for shelf-life stability classification because most biltong fall in the range of $20-50 \%$ moisture content and $a_{w} 0.60-0.90$ (Leistner, 1987).

\section{Biltong market size}

Biltong has become the popular choice for consumers as a healthy and convenient 'go-to' snack food, as has jerky in the USA (Miller et al., 1988; Carr et al., 1997). Nortje et al. (2005) and Dzimba et al. (2007) reported that consumers prefer biltong with a higher moisture content, but this is not supported by consumer studies to the authors' knowledge.

There is currently no official estimation of the annual biltong production in South Africa. Van der Riet (1982) stated that several producers were producing over 100 tonnes of biltong yearly with an estimated total biltong production closer to thousands of tonnes. In 2003, more than 20 years later, Gull Foods (one of the companies that produces biltong in South Africa) produced 80 000-90000 units, from 80 to $180 \mathrm{~g}$, per month (Attwell, 2003), which corresponds to 6 to 16 tonnes per month. In 2015, Closwa Biltong, the largest manufacturer of biltong products in Namibia, produced up to 660 tonnes of product per annum (Fourie, 2015), while a local Cape Town manufacturer, Cape Deli, produced 480 tonnes per annum (Nel, 2016).

Biltong has gained popularity in international markets such as Namibia, UK, Australia, New Zealand, USA, Canada, and in a number of countries in Europe (for example Denmark, Netherlands, Switzerland). Some of these markets sell biltong through Internet sites and stores that supply traditional South African products. In the UK, Attwell (2003) stated that only one biltong factory had been established (in 1982) as an EUc-accredited factory that produced biltong.

Biltong producers in South Africa have difficulty in exporting products owing to the 'virtually nonexistent opportunities for export without an EU and HACCP-certified factory' (Attwell, 2003). The high cost of raw meat and consumer demand for quality and consistency is a problem for South African and international 
markets. The large commercial biltong factories in South Africa are in the process of EU certification so that they can export their products (Nel, 2016).

\section{Meat selection, preparation and processing of biltong}

Beef, ostrich, game (mainly kudu, springbok and gemsbok on a commercial scale, particularly gemsbok in Namibia) and even chicken meat are commonly used to make biltong (Van Wyk, 2007; Naidoo \& Lindsay, 2010a; Strydom \& Zondagh, 2014). Lately, there has been an increase in the production of pork biltong, although rancidity is still of concern among processors. Fresh and thawed meat can both be used. The most popular muscles for biltong are silverside (biceps femoris), topside (semimembranosus), thick flank (rectus abdominus), eye of round (semitendinosus), and fillet (psoas) (Van Tonder \& Van Heerden, 1992; CSIR, 2001; Van Wyk, 2007; Strydom \& Zondagh, 2014), with topside being preferred. Traditionally, the longissimus dorsi muscle from older cows (C-class) was used to make biltong. However, in modern large facilities, it is too expensive.

When cutting the meat, the connective tissue is removed and the resulting meat is cut into long strips. The dimensions depend on muscle type and personal preference. Suggestions include a width/thickness of 2.5-5 cm (Van Tonder \& Van Heerden, 1992); the thicker the strips the longer the drying period. Typical biltong strips reported in the literature are $20-40 \mathrm{~cm}$ long and $4-15 \mathrm{~cm}$ wide (Van der Riet, 1982; CSIR, 2001; Naidoo \& Lindsay, 2010b). Biltong products include thin snack sticks, crisps, small nuggets/bites, strongly spiced chilli bites, and even flat wheels and discs.

Traditionally, the meat is cut parallel to the meat fibres (CSIR, 2001) as this is thought to give the most efficient salt and spice absorption and best quality (texture) although there is no scientific evidence to support this. This aspect warrants further research. It has also been suggested that the meat should be cut diagonally across the grain to give better eating quality and appearance.

Biltong can be lean (no fat on the outside) or fatty (a layer of fat on a surface), both of which are popular among consumers. However, excess fat should be trimmed from the meat as it may cause rancidity (Heinz \& Hautzinger, 2007; Strydom \& Zondagh, 2014) and more time for the meat to absorb salt (Van Tonder \& Van Heerden, 1992). Fat can also decrease water diffusivity, which was seen in a study on the drying of pepperoni sausages, where a lower fat content resulted in increased water diffusivity (Palumbo et al., 1977). Ostrich and game species seldom have fat depots such as subcutaneous fat and therefore produce lean biltong.

\section{Biltong salting and spicing}

Several methods are used when salting and mixing biltong with spices and sometimes vinegar. The meat can be dipped in dry spices (Taylor, 1976; Van der Riet, 1976b; CSIR, 2001), or in dry spices followed by a hot acidic liquid (vinegar) (Leistner, 1987), dipped in an acidic liquid, drained, and dipped in dry spices, or dipped in an acidic liquid and spice mix (Naidoo \& Lindsay 2010b). Before drying, salted and spiced meat strips can be stored. Traditionally storage was at ambient temperature, but nowadays it is likely to be at $4{ }^{\circ} \mathrm{C}$ (Burfoot et al., 2010). Storage time may vary, and was reported to be $18-20$ hours at $4-8{ }^{\circ} \mathrm{C}$ in the study of Naidoo \& Lindsay (2010b).

Salting is a method of preservation that causes changes in muscle proteins and texture by modifying myofibrillar protein solubility and swelling muscle fibres. This relates to an increase in the water-binding and water-holding capacities of the salt concentration and $\mathrm{pH}$ usually encountered in processed meat products (Offer \& Trinick, 1983; Offer et al., 1989; Oliveira et al., 2012; Toldrá, 2015). Salt preservation also acts by decreasing $a_{w}$ so there is less available for microbial growth, which leads to increased shelf-life. Swelling occurs because of the chloride ions that bind to the protein filaments, which increases the electrostatic repulsive force between them, causing the protein structure to unfold and swell (Cheng \& Sun, 2008).

Salt has been added to biltong at levels of 2.5-4\% (Taylor, 1976; Van der Riet, 1976b; Van der Riet, 1982). A number of studies use spice mixes that contain salt, but the salt content is not mentioned and cannot always be determined in the end product (Nortje et al., 2005; Dzimba et al., 2007; Naidoo \& Lindsay, $2010 \mathrm{~b}$ ). It has been reported that $2.5 \%$ of salt in the formulation gives an acceptable taste over a wide range of moisture contents, but can be increased up to 4\% (Van der Riet, 1982). Van der Riet (1982) stated that dry salting, although it can result in uneven distribution of salt, is an easier process and more economical than brining, namely submerging meat in a saturated salt brine.

Vinegar may be added during the salting and spicing step (Van den Heever, 1970; Van der Riet, 1982; Naidoo \&Lindsay, 2010a; Naidoo \& Lindsay, 2010b; Strydom \& Zondagh, 2014), which plays a role in inhibiting microbial growth, adding to the flavour, and influencing water-binding capacity (below). Brown spirit vinegar and apple cider vinegar are most commonly used in biltong production (Naidoo \& Lindsay, 2010a; Strydom \& Zondagh, 2014). Previously, vinegar was added to biltong at a level of $\sim 3 \%$ (Van den Heever, 
1970) and $~ 6 \%$ (Naidoo \& Lindsay, 2010b). Other ingredients that are commonly used include black pepper, coriander and brown sugar.

Preservatives have been permitted for use in biltong production, as stated under the Foodstuff, Cosmetics and Disinfectants Act 54 (1972) (Table 2).Other preservatives that are mentioned on the labelling of commercial biltong include sodium bisulphite and sodium benzoate. Pimaricin and potassium sorbate are the most commonly used preservatives, and are included in most spice packs for salting and spicing biltong. The use of $1000 \mathrm{ppm}$ sorbic acid was effective in retarding the development of the growth of total microorganisms (Taylor, 1976) and moulds (Van den Heever, 1970; Van der Riet, cited by Van der Riet, 1982). Sodium nitrates/nitrites have been added to prevent microbial spoilage, and also for a red colour (CSIR, 2001; Strydom \& Zondagh, 2014).In one study, nitrate measured between 10 and 860 ppm (Osterhoff \& Leistner, 1984). However, they are reputedly no longer be used in commercial biltong. Nitrates/nitrites are commonly used in salted and dried products globally for their contribution to the red colour, and their role on flavour development and microbial security. The lack of nitrates/nitrites in biltong does not seem to lead to an undesirable colour or flavour for consumers. The inverse has been mentioned in CSIR (2001), although not supported by a sensory analysis. However, biltong microbial quality and shelf-life could be affected because nitrates/nitrites allegedly have antioxidant and antimicrobial properties. There is a dearth of research on the level of nitrites/nitrates (preservatives in general) in commercial biltong, and whether they fall within the legislation limits. Consumer acceptance of preservatives being added to such a product and their impact on microbial quality and shelf-life have not been recorded either.

Table 2 Regulations pertaining to food preservatives and quantities permitted for use in biltong according to the Foodstuff, Cosmetics and Disinfectants Act No 54 (1972)

\begin{tabular}{|c|c|}
\hline Preservative & Quantity permitted (mg/kg or mg/L) \\
\hline Pimaricin & 6 \\
\hline Potassium and sodium nitrates & 200 total nitrate, expressed as sodium nitrate \\
\hline Potassium and sodium nitrites & 160 total nitrite, expressed as sodium nitrite \\
\hline Sorbic acid & 2000 \\
\hline
\end{tabular}

On a large scale, tumbling is used to help mix ingredients during biltong manufacturing. Tumbling is performed at the factory temperature (usually $10^{\circ} \mathrm{C}$ ), sometimes under vacuum. Tumbling is used as a method of accelerating food production processes and usually in meat production as a post treatment to brining (Toldrá et al., 2010; Hui, 2012). It accelerates salt diffusion (migration), enhances tenderness and juiciness, and increases product yield. During this mechanical operation, meat pieces fall and hit paddles in a rotating drum, causing cellular disruption of the meat tissue and allowing a more even distribution of the salt. It must be done at a relatively low speed because if it is too fast, it could lead to heat production, mechanical damage and poor salt distribution, resulting in lower or poor quality products (Toldrá et al., 2010). This occurs under a vacuum to offset the potential problem of incorporating air into protein exudates, and is a continuous or intermittent treatment. Brine injection and tumbling have been compared with dry salting in pastirma processing (Guner et al., 2008). Advantages of tumbling in biltong production, from an industrial viewpoint, are limited handling of large quantities of meat, reduced processing time - waiting for 24 hours is the norm for traditional processing - costs and increased output yields. Tumbling could promote the distribution of ingredients more quickly and uniformly within the meat. However, the diffusion of salt in biltong during salting and spicing the traditional way or when the meat is tumbled with or without a vacuum and during its subsequent drying and storage has not been studied.

\section{Biltong drying}

The traditional drying of biltong is done by hanging the meat strips outside for one to two weeks, depending on ambient conditions (Van der Riet, 1982). The meat strips are hung on hooks (wire or plastic) in shady areas, usually in winter because the temperature, humidity and wind conditions are considered ideal. These days, biltong is still made at a household level using this method or with a small box equipped with a fan and a light. As biltong became more in demand, these traditional methods were adapted for commercial purposes. At commercial level, a variety of drying equipment has been used in biltong production, from a basic room with fans and heaters to controlled drying chamber units (Van der Riet, 1982). Table 3 
summarizes information in scientific literature about biltong drying. Among these studies, Taylor (1976) followed the moisture content of biltong during six days of drying at $35{ }^{\circ} \mathrm{C}$ temperature, $30 \%$ relative humidity and $3 \mathrm{~m} / \mathrm{s}$ air velocity, which was said to replicate industrial conditions. In the industry, biltong is usually dried at low temperatures $\left(25-30^{\circ} \mathrm{C}\right)$. Dryers that are most frequently used are only temperature controlled but some can measure relative humidity. However, no data are available for relative humidity and air velocity conditions in the industry. Large biltong producers like to use drying chambers in which temperature and relative humidity are controlled. Biltong is usually dried to a $50 \%$ weight loss or more to accommodate other consumer preferences (Strydom \& Zondagh, 2014).

Table 3 Biltong drying equipment and specifications in scientific studies

\begin{tabular}{|c|c|c|c|c|c|}
\hline Equipment & Temperature $\left({ }^{\circ} \mathrm{C}\right)$ & $\begin{array}{l}\text { Relative humidity } \\
(\%)\end{array}$ & $\begin{array}{c}\text { Air } \\
\text { velocity } \\
(\mathrm{m} / \mathrm{s})\end{array}$ & Time & Reference \\
\hline $\begin{array}{l}\text { Home-made dryer } \\
\text { equipped with a light } \\
\text { bulb }\end{array}$ & 25 & ns & ns & 4 days & $\begin{array}{l}\text { Naidoo \& } \\
\text { Lindsay, 2010b }\end{array}$ \\
\hline $\begin{array}{l}\text { Environmental } \\
\text { chamber }\end{array}$ & $\begin{array}{c}\text { Set: } 22.2 \text { Range: } \\
\text { 20-22 }\end{array}$ & $\begin{array}{c}\text { Set: } 50 \text { Range: } \\
\text { 38-64 }\end{array}$ & ns & $\begin{array}{l}17-26 \text { days } \\
\text { until } a_{w}<0.6\end{array}$ & $\begin{array}{l}\text { Burnham et al., } \\
2008\end{array}$ \\
\hline Drying cabinet & 35 & ns & ns & ns & $\begin{array}{l}\text { Dzimba et al., } \\
2007\end{array}$ \\
\hline Drying chamber & $28-32$ & 70 & ns & 1 day & $\begin{array}{l}\text { Nortje et al., } \\
2006\end{array}$ \\
\hline Drying chamber & $28-32$ & 70 & ns & 2 days & $\begin{array}{l}\text { Nortje et al., } \\
2005\end{array}$ \\
\hline $\begin{array}{l}\text { Drying chamber } \\
\text { settings }\end{array}$ & 35 & 30 & 3 & 6 days & Taylor, 1976 \\
\hline
\end{tabular}

ns: not specified

Mass transfers during drying of meat products involve the migration of water to the environment (external), leading to a decrease in $\mathrm{a}_{\mathrm{w}}$ and the continuation of the distribution of salt and other compounds in the product itself (internal) (Comaposada Beringues, 1999). Drying curves illustrate the water transfer phenomena during drying. They are called drying kinetics when the decrease in moisture content is plotted against drying time. A typical drying curve is represented in Figure 1.

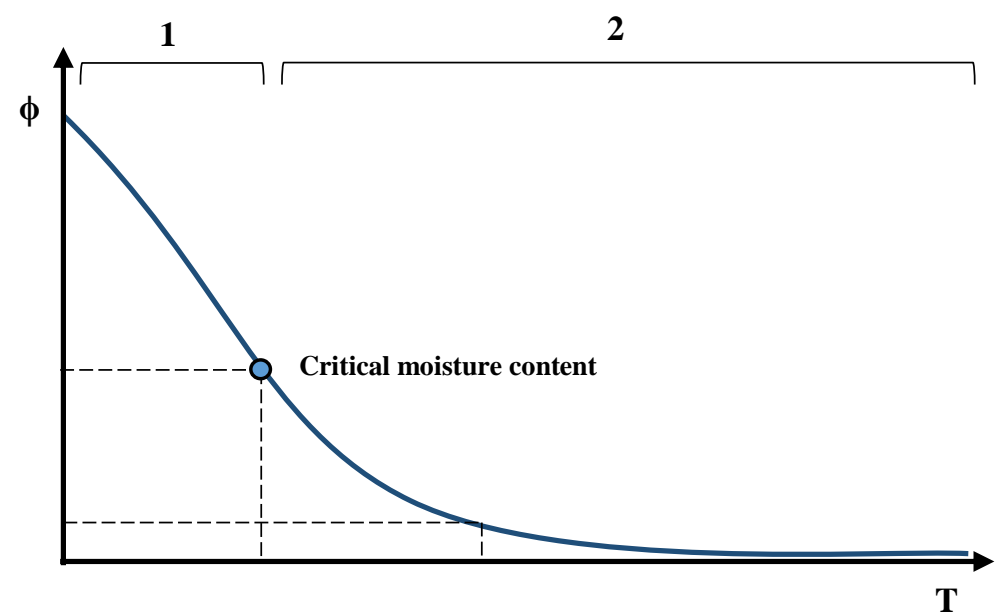

Figure 1 Ideal drying kinetics curve (adapted from Comaposada Beringues, 1999)

$\Phi=$ moisture content (dry basis), $T=$ drying time

1 - Constant-drying rate period

2 - Falling-drying rate period

When studying the drying of any food type it is important to consider the water sorption isotherm. This shows the relationship between moisture content and $a_{w}$. The water sorption isotherm, type II, showing the 
moisture isotherm (sigma-shaped curve) for most products (cereals, dry products, meats, cheese etc.), is depicted in Figure 2.

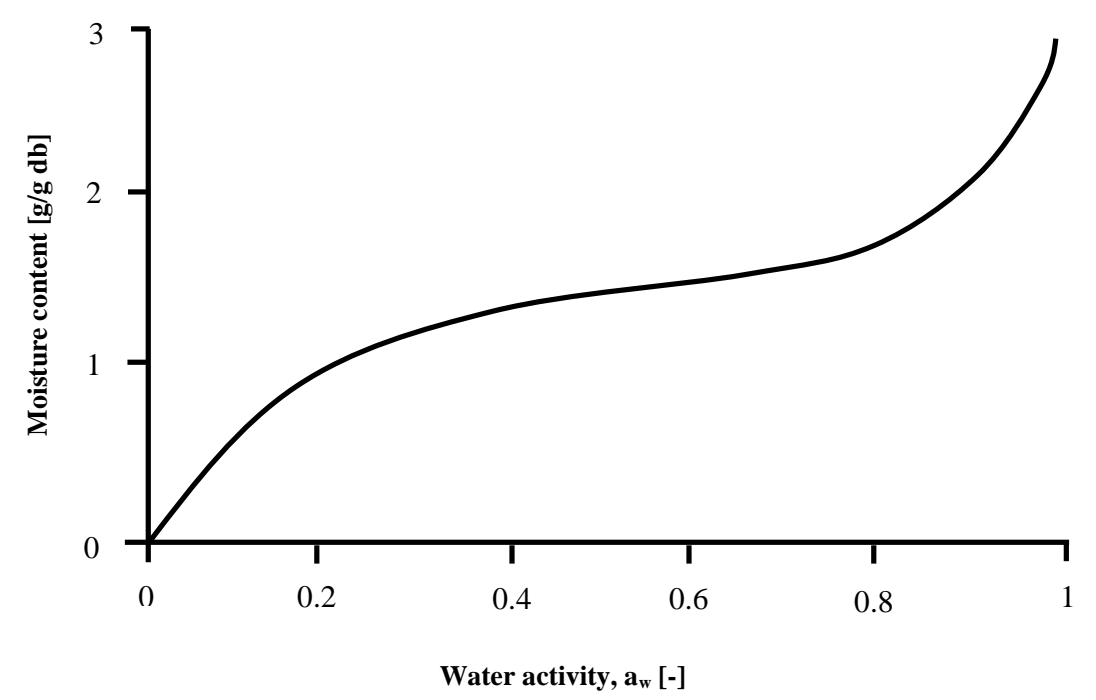

Figure 2 Water sorption isotherms, Branauer-Emmett-Teller classification, type II

The addition of salt to the product influences the relationship between moisture content and $\mathrm{a}_{\mathrm{w}}$, as shown in Figure 3 (Van der Riet, 1976b). This author plotted the moisture content wet basis instead of the usual moisture content dry basis, as a function of $a_{w}$. An increase in salt results in an increase in the moisture content for the same $a_{w}$.

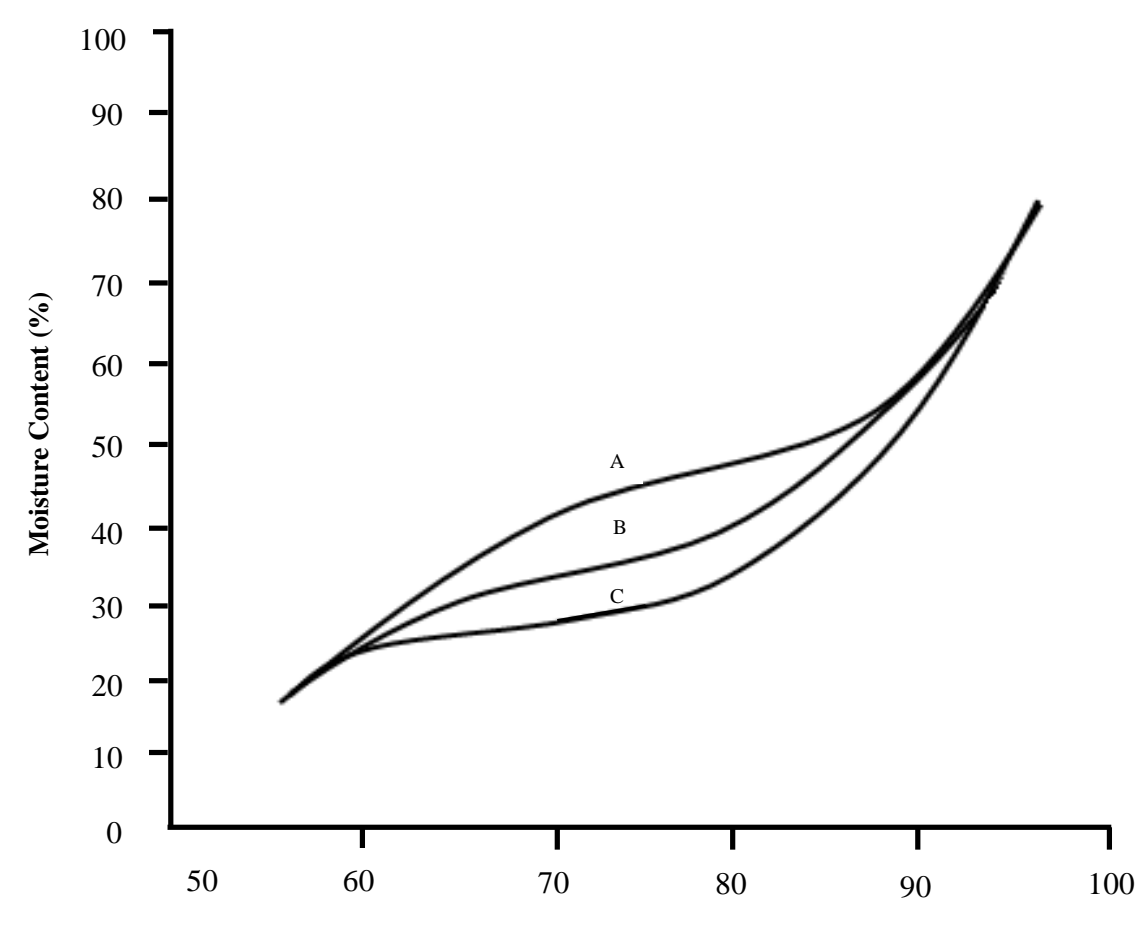

Water activity at $25^{\circ}$

Figure 3 Relation between moisture content and water activity $\left(a_{w}\right)$ of biltong produced with $4 \%(A), 2.5 \%$ (B), and 1\% (C) salt (adapted from Van der Riet, 1976b) 
The external mass transfer is dependent on air flow conditions, namely air temperature, relative humidity and air velocity, and product shape/dimensions. The rate of drying will be high if there is a large difference between vapour pressure at the meat surface and water in the air (Comaposada Beringues, 1999). In a dryer that is temperature controlled only, the air temperature influences the relative humidity of the drying chamber and hence the rate of drying. By raising the air temperature, the relative humidity lowers and the rate of drying increases. However, if the air temperature rises too high $\left(>50{ }^{\circ} \mathrm{C}\right)$, then the biltong starts to develop a cooked flavour (CSIR, 2001). Air speed is an important factor that is seldom considered when optimising drying procedures. Air velocity affects the rate of drying through the mass transfer coefficient (Saravacos \& Kostaropoulos, 2002). The mass transfer coefficient moves hot air towards the meat, removing moisture from the meat surface and the drying equipment, and influencing the drying rate. Therefore, lower speeds reduce the drying rate while higher speeds increase it. Some studies have been conducted on the drying kinetics of meat (Trujillo et al., 2007; Clemente et al., 2009; Chabbouh et al., 2011; Hii et al., 2014; Ahmat et al., 2015; Kucerova et al., 2015; Petrova et al., 2015). These covered the effects of drying parameters, namely temperature, relative humidity, and air velocity, and meat thicknesses and also modelled these kinetics.

Among the changes that occur due to the drying process, surface crust formation (Bellagha et al., 2007) and shrinkage (Duan et al., 2011) may be of concern for biltong drying. 'Case-hardening' or surface crust formation means that the meat surface is dry and hard, but the inside is still moist. This can occur if there are high drying temperatures, and/or high air velocity and low relative humidity, as these result in a shorter drying time causing a high drying rate and thus high moisture loss from the meat surface. If the surface is too dry, the moisture inside the meat cannot move out quickly enough (Comaposada Beringues, 1999; Serra et al., 2005). Shrinkage is caused by loss of water, which causes stress in the cellular structure of foods and is affected by the volume of removed water, mobility of the solid matrix, and the drying rate (Mayor \& Sereno, 2004). The presence of collagen can also influence shrinkage, because it tends to dry faster than the meat. When heat is applied collagen is transformed to soluble gelatin. On prolonged heating and drying, the soluble gelatin binds the muscle fibres, forming an intact structure, which causes the meat to bend, and results in an increased toughness (Huang \& Nip, 2001). If the collagen dries faster than the meat, this causes shrinkage, which could result in the biltong becoming undesirable and difficult to eat. Research on vegetables has shown that the shape and size of the samples have minor effects on volumetric shrinkage (Hatamipour \& Mowla, 2003; Mulet et al., 2000). Clemente et al. (2009) studied the shrinkage of pork meat during drying, and concluded that with moderate drying temperatures $\left(25^{\circ} \mathrm{C}\right)$ and air speeds $(0.6-2.8 \mathrm{~m} / \mathrm{s})$, the volume shrinkage and water losses that occur are linearly related. Okos et al. (1992), on the other hand, stated that in dried meat products, $40-50 \%$ of the shrinkage may occur in the early drying stages.

Water-holding capacity is related to $\mathrm{pH}$ (Figure 4). It is lowest at the isoelectric point of the proteins (about 5.0 to 5.2 ) because positive and negative charged groups are equal, resulting in proteins being more attracted to each other and reducing the amount of water that can be attracted and held by them. Figure 4 also shows that salt increases water-holding capacity for a $\mathrm{pH}$ higher than the isoelectric point and decreases the isoelectric $\mathrm{pH}$ of meat. When making beef biltong, a high $\mathrm{pH}$ of the raw material is not common but when working with game meat this is a regular problem owing to ante mortem stress that is experienced by the animal (Hoffman \& Wiklund, 2006; Hoffman et al., 2007). The accumulation of lactic acid in its muscles lowers $\mathrm{pH}$ and results in good eating quality. If an animal is stressed at the time of death muscle glycogen reserves are depleted and the $\mathrm{pH}$ does not decline noticeably. A high $\mathrm{pH}$ leads to increased water-holding capacity, resulting in dark firm dry (DFD) meat. The water in the meat is tightly bound to the muscle structure. When using DFD meat in biltong production, it is hypothesised that because the water is tightly bound within the meat, it may take longer to remove and therefore delay the drying process. However, this hypothesis needs to be clarified. The effect of increased water-holding capacity and high $\mathrm{pH}$ on microbial spoilage also needs further research (see next section), which would be beneficial to the game biltong industry because currently drying parameters and time are the same, irrespective of whether beef or game is processed. Moreover, the addition of vinegar, which should result in lower $\mathrm{pH}$, may also influence the drying rate because low $\mathrm{pH}$-values increase the drying rate in fermented meats owing to the decrease in water-holding capacity when the pH is around the isoelectric point (Toldrá, 2015). 


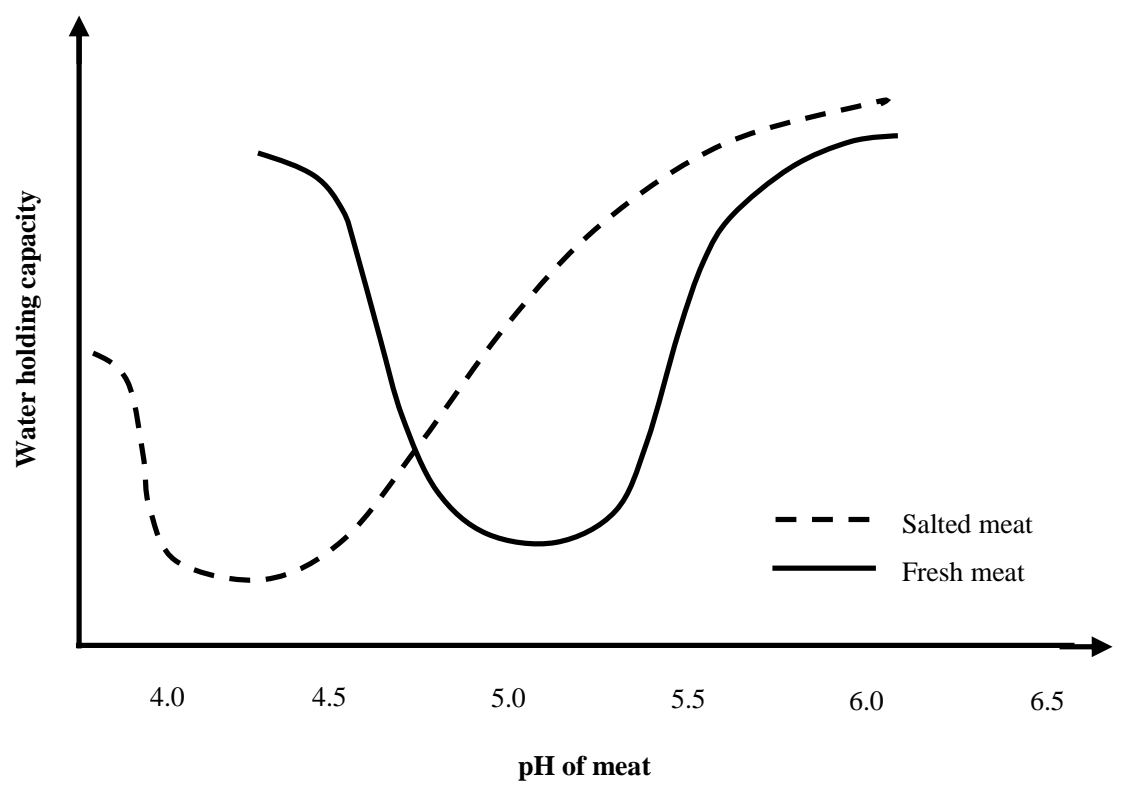

Figure 4 Relationship between water-holding capacity and pH in meat (adapted from Xiong, 2004)

\section{Biltong packaging and storage}

Biltong is packaged and stored in various ways. Most butcheries in South Africa sell biltong in loose paper bags or over-wrapped trays, dependent on the type that is being sold (slabs, sliced, sticks, etc.). Consumers store biltong in brown bags or closed plastic containers when making biltong at home. Industrially produced products, however, are sold in modified atmosphere packaging (MAP) to give them a longer shelf-life (Van der Riet, 1982; Strydom \& Zondagh, 2014). Vacuum packaging (VP) is still used, but is not suitable for high moisture biltong as it causes the biltong to stick together and to lose its visual appeal. Biltong is sometimes packaged in a sealed bag using none of these technologies, but this is not common.

It is commonly known that microbial growth is dependent on oxygen availability. Microorganisms can be classified as aerobic (e.g. moulds), anaerobic (e.g. Clostridium spp.), and facultative anaerobes (e.g. Salmonella spp., Staphylococcus aureus, and yeasts) (Day, 2008; Mullen \& McDowell, 2011). Nitrogen and carbon dioxide $\left(\mathrm{CO}_{2}\right)$ are frequently used in MAP to manipulate the environment as a means to control bacterial growth. Nitrogen replaces oxygen in the packaging, and therefore inhibits the growth of strict aerobic microorganisms such as moulds, while $\mathrm{CO}_{2}$ exerts an antimicrobial effect on spoilage microorganisms and pathogens, which are aerobic, and thereby reduces or prevents the growth of these microorganisms (Day, 2008). VP results in a low oxygen environment and therefore inhibits the growth of aerobic microorganisms, similarly to MAP. This type of packaging, however, has higher residual oxygen than MAP. Research on dry-cured hams showed that no significant decrease in mesophilic aerobic colonies in MAP compared with VP, indicating no differences in microbial quality between differing packaging conditions (García-Esteban et al., 2004; Parra et al., 2010). A report by Aas et al. (2010) stated that MAP inhibits halophilic bacteria in salted cod. Halophilic bacteria are strictly aerobic and therefore MAP has a growthinhibiting effect. Theoretically, MAP should be the best packaging for biltong as it should help to inhibit microbial growth and retain the quality characteristics expected by consumers.

However, there has been no research to show the impact that packaging has on the quality and shelflife of biltong. However, unpackaged biltong should not be stored in moist warm environments because it may reabsorb moisture and become more susceptible to microbial growth (Burfoot et al., 2010). Studies on salted cod have reported that it is important to maintain an equilibrium between $a_{w}$ in the product and the relative humidity in the surrounding air. A higher relative humidity than product $a_{w}$ results in weight gain because the product absorbs moisture. The opposite occurs when the relative humidity is lower than the product $a_{w}$ (Doe et al., 1982). The same principle should apply to salted and dried meat products. When biltong is stored by hanging in the open air, the storage conditions are also important as these could affect the colour, texture, moisture content and microbial stability of the product.

\section{Microbial quality and shelf-life of biltong}

Biltong is considered a safe product. However, there has been concerns about its microbial profile. Studies assessed the levels of organisms that are naturally present in a variety of biltong that was bought 
from various stores throughout South Africa (Van der Riet, 1976a; Wolter et al., 2000; Mhlambi et al., 2010; Naidoo \& Lindsay, 2010c; Naidoo \& Lindsay, 2010a; Petit et al., 2014) and Botswana (Matsheka et al., 2010). Burfoot et al. (2010) compiled a summary of results, which concluded that commercial biltong has total viable counts up to $7 \log \mathrm{cfu} / \mathrm{g}$, Enterobacteriaceae and coliforms up to $4 \log \mathrm{cfu} / \mathrm{g}$, yeasts up to $7 \log$ $\mathrm{cfu} / \mathrm{g}$, moulds up to $5 \mathrm{log} \mathrm{cfu} / \mathrm{g}$, lactic acid bacteria up to $8 \mathrm{log} \mathrm{cfu} / \mathrm{g}$, and Staphylococci up to $8.5 \mathrm{log} \mathrm{cfu} / \mathrm{g}$.

According to the Food Safety and Inspection Services (FSIS), major concerns in ready-to-eat meat products are Salmonella spp., Listeria monocytogenes and Escherichia coli 0157:H7 (Levine et al., 2001). Spoilage microorganisms are those that usually affect the quality of biltong and its shelf-life. These include coliforms, lactic acid bacteria, yeasts and moulds (Taylor, 1976; Naidoo \& Lindsay, 2010a).

Yeast and mould growth often occur on biltong (Van der Riet, 1976a; Osterhoff \& Leistner, 1984; Wolter et al., 2000; Mhlambi et al., 2010; Matsheka et al., 2014; Petit et al., 2014). Once present, yeast and moulds increase over time and eventually dominate the spoilage microorganism profile (Cook, 1995). This occurs in most dried meat products because yeasts and moulds can survive in a wide range of water activities (>0.61) (Betts \& Everis, 2008). Some studies showed that yeasts are predominant compared with mould (Van der Riet, 1976a; Osterhoff \& Leistner, 1984; Petit et al., 2014). One study showed that yeasts were present in 19 out of 20 biltong samples, ranging between 1.0 and $5.5 \mathrm{log} \mathrm{cfu} / \mathrm{g}$, while moulds were present in only 6 of 20 samples, ranging between 1.0 and 5.3 log cfu/g (Van der Riet, 1976a). Matsheka et al. (2014) found 55 yeast and mould species, which belonged to more than nine genera. Candida yeasts and Aspergillus and Penicillium filamentous moulds were the most common. Other genera found on biltong included Pichia, Eurotium, Fusarium, Cladosporium and Debaryomyces (Matsheka et al., 2014). Yeasts and moulds induce economic losses for the biltong industry (Van der Riet, 1982) and constitute a recurring problem.

Candida, Torulopsis, and Debaryomyces are the dominant yeasts that are isolated in meat and meat products (Cook, 1995). Yeasts are substantially represented in the total biltong ecology, and have been seen to range between 2.0 and $7.0 \mathrm{log} \mathrm{cfu} / \mathrm{g}$ (Wolter et al., 2000). Debaryomyces hansenii is the most common yeast species in dried-cured products (Jessen, 1995; Núñez et al., 1996) and biltong (Wolter et al., 2000).

Moulds may produce mycotoxins (Van der Riet, 1976a; Matsheka et al., 2014). Aspergillus, Penicillium. Fusarium, Eurotium, and Mucor are frequently found on dried-cured meat products (Cook, 1995; Asefa et al., 2009; Sonjak et al., 2011). These are also often found on biltong (Van der Riet, 1976a; Van der Riet, 1982; Wolter et al., 2000; Matsheka et al., 2014). Various studies have been conducted on the presence of yeast and moulds and the aflatoxins they produce in meat products (Markov et al., 2013). A study by Van der Riet (1976a) focused on biltong, concluded that Aspergillus flavus, which can produce aflatoxins, was most frequently isolated from commercial biltong samples, being present on $60 \%$ (12 out of 20 ) of the samples. Other yeast and moulds that were isolated from these commercial samples are known to produce mycotoxins. However, the study did not investigate these. Aspergillus glaucus genera is often present, but does not produce mycotoxins. It is often misidentified as Aspergillus flavus, which produces aflatoxin (Van der Riet, 1976a; Van der Riet, 1976b; Van der Riet, 1982). The production facilities of drycured meat products are said to be linked to the growth of Penicillium spp, while Fusarium has been linked to production and air contamination in the facilities (Núñez et al., 1996).

Pathogenic bacteria are also a concern with biltong as these have also been found on commercial biltong. Studies have indicated the presence of these pathogenic microorganisms, namely Salmonella spp. detected in 7 out of 47 samples (Prior \& Badenhorst, 1974) and 2 in 60 samples (Van den Heever, 1970) and Listeria monocytogenes in 2 of 150 samples (Naidoo \& Lindsay, 2010a). Among Staphylococcus strains, coagulase-negative strains such as S. pasteuri, S. saprophyticus, and S. arlettae are predominant. (Naidoo \& Lindsay, 2010a; Matsheka et al., 2014). S. aureus was detected only in the study of Naidoo \& Lindsay (2010a) with three strains of the 159 Staphylococcus isolates being confirmed as $S$. aureus. Another study showed that $S$. aureus in most biltong sampled exceeded $100 \mathrm{cfu} \cdot \mathrm{g}^{-1}$ (Shale \& Malebo, 2011).

In South Africa, the commercial biltong industry uses the microbiological requirements as stated in the South African National Standards (SANS) 885. These show the maximum permitted microbial levels at the end of the shelf-life of the product. They do not include microbiological requirements for coliforms, yeasts and moulds, but these have been mentioned in a committee draft. Table 4 gives a summary of the microbiological specifications for biltong and biltong-like products according to these standards.

Dried meats, such as biltong, beef jerky (North America), charqui (South America) and Rou Gan (China), can be stored at ambient temperatures because of their $a_{w}$ being less than 0.90 (Leistner, 1987). The $\mathrm{a}_{\mathrm{w}}$ limit for ambient storage of a meat product can be increased up to 0.95 if the $\mathrm{pH}<5.2$ (Robertson, 2006). It is also important to try to maintain the $a_{w}$ at $\leq 0.61$ to avoid microbial spoilage (Leistner, 1987). 
Table 4 Microbiological specifications for dried meat products (SANS 885:2011) for total viable counts, coliforms, yeasts and mould, Escherichia Coli, Salmonella spp., Staphylococcus aureus, and Listeria monocytogenes

\begin{tabular}{lccccccc}
\hline \multirow{2}{*}{ Category $^{*}$} & \multicolumn{7}{c}{ Microbiological requirements (log cfu/g) } \\
\cline { 2 - 8 } & TVC & E. coli & Salmonella spp. & S. aureus & L. monocytogenes & CF & YM \\
& $<6$ & $<1$ & $0 / 25 \mathrm{~g}$ & $<1.3$ & $<2$ & $<2$ & $<3$ \\
Class 3 & $<6$ & $<1$ & $0 / 25 \mathrm{~g}$ & $<1.3$ & $<2$ & $<2$ & $<3$ \\
Class 5 & $<6$ & $<1$ & $0 / 25 \mathrm{~g}$ & $<1.3$ & $<2$ & $<2$ & $<3$ \\
Class 8 & $<$ & &
\end{tabular}

*Class 3: whole muscle, uncured, no/partial heat treated, dried products such as uncured biltong; Class 5: whole muscle, uncured, no/partial heat treated, dried products (cured biltong); Class 8: comminuted, uncured, no/partial heat treated, dried products such as droëwors, biltong wheels and discs

\#Committee draft: A draft of the legislation with possible amendments that can be made to the current legislation

According to the literature, biltong has not been given a shelf-life period. Biltong companies in South Africa suggest a three-month shelf-life for unopened packages, with the recommendation to store in refrigeration and consume within three days of opening (Fourie, 2015).

The microbial growth during storage of biltong has not been studied extensively. Ground biltong challenged with moulds isolated from commercial biltong did not allow for mould development during two months' storage at $25^{\circ} \mathrm{C}$ when the $a_{w}$ was 0.70 , although limited growth was noticed on samples with $a_{w}$ of 0.80, 0.78 and 0.72 (Van der Riet, 1976b; Van der Riet, 1982). Unfortunately, this report does not state the salt content of the product and whether vinegar was used.

Regarding the fairly high levels of spoilage microorganisms that biltong can contain, it would be interesting to assess their growth throughout the production process and shelf-life at commercial level. Moreover, although they could influence these, the effects of factors such as the extent of drying, the salting/spicing technique and the type of packaging still need to be researched.

\section{Hurdle technology in biltong processing}

Biltong is produced in several microbial growth-limiting steps, namely salting and spicing, adding vinegar, and drying. Hurdle technology refers to the control of two or more factors to inhibit microbial growth in food products. Factors that influence microbial growth can be intrinsic, namely properties of the food product itself; and extrinsic, namely properties of the environment to which the food is exposed (Betts \& Everis, 2008). Intrinsic factors include $\mathrm{pH}$ (acidity measurement), $\mathrm{a}_{\mathrm{w}}$ (moisture and salt content), and preservative content (natural or added). Extrinsic factors that can be controlled include the temperature during processing and storage, the use of packaging with modified atmospheres, heat (sterilization and pasteurization) and light. The combination of these factors results in a synergistic effect, which does not necessarily result in cell death, but slows down microbial growth. Some of the microorganisms growth factors often found in biltong are depicted in Table 5.

The biltong manufacturing process takes place at different temperatures: meat preparation and curing at $4-10^{\circ} \mathrm{C}$, drying at $20-35^{\circ} \mathrm{C}$, and storage at temperatures up to $25^{\circ} \mathrm{C}$. Naidoo (2010) and Naidoo \& Lindsay (2010a) studied in vitro growth at various temperatures of strains of Listeria monocytogenes, Staphylococcus aureus, Staphylococcus pasteuri, and Salmonella spp., some which were isolated from biltong. As usually observed, Listeria monocytogenes grow at refrigeration temperature of $4{ }^{\circ} \mathrm{C}$ and drying temperatures of $25-30^{\circ} \mathrm{C}$, while Staphylococcus aureus, Staphylococcus pasteuri spp., and Salmonella spp. grow better at $25-37{ }^{\circ} \mathrm{C}$. Yeasts and moulds thrive in a wide range of temperatures and can proliferate during low temperature storage (Cook, 1995). Therefore, depending on the storage conditions, this results in a varying microbial profile.

Naidoo (2010) and Naidoo \& Lindsay (2010a) indicated that some S. aureus strains showed growth at more than $20 \%$ salt concentration. However, they stated that at salt concentration of $\geq 3 \%$, the production of enterotoxin was drastically reduced. Organic acids such as brown spirit vinegar and apple cider vinegar, which are used in biltong production, were inadequate to inhibit the growth of all the strains, although acetic acid in vinegars is known to retain their bacteriostatic and bacteriocidal properties, even at minimal concentrations (Entani et al., 1998). 
Table 5 Minimum* growth factors for food-borne microorganisms (adapted from Betts \& Everis, 2008)

\begin{tabular}{lcccc}
\hline Microorganism & $\mathbf{p H}$ & $\mathbf{a}_{\mathbf{w}}$ & Anaerobic growth & Temperature ${ }^{\circ} \mathbf{C}$ \\
\hline Salmonella spp. & 3.8 & $0.92-0.95$ & Yes & $4-5.2$ \\
Staphylococcus aureus & 4.0 & 0.83 & Yes & 7 \\
Bacillus cereus & 4.9 & $0.93-0.95$ & No & 4 \\
Listeria monocytogenes & 4.3 & 0.92 & Yes & -0.4 \\
Escherichia coli & 4.4 & 0.93 & Yes & $7-8$ \\
Clostridium perfringens & 4.5 & $0.93-0.95$ & Yes & 12 \\
Lactic acid bacteria & 3.5 & 0.90 & Yes & 4 \\
Yeasts & 2.0 & 0.62 & Yes & 10 \\
Moulds & 2.0 & 0.61 & No & 10 \\
\hline
\end{tabular}

${ }^{*}$ Factor minimum needed for growth of microorganisms when all other conditions are optimum for growth

The literature has dealt much less with microbial changes throughout the production process (Taylor, 1976) than the survival of inoculated pathogens afterwards. In experimental work by Burnham et al. (2008 biltong was produced on a small scale, inoculated with pathogenic bacteria, and dried for 17-26 days (20-22 ${ }^{\circ} \mathrm{C}, 38-6 \%$ relative humidity). Reductions were noted of Salmonella between 2.0 and 4.2 log, E. coli between 2 and $4.4 \mathrm{log}$, L. monocytogenes between 1.0 and $4.0 \mathrm{log}$, and $S$. aureus between 0 and $2.6 \mathrm{log}$. This study was conducted to see the extent to which the biltong process met the standards for jerky (USDA, 2014). USDA requires processes to achieve 5-6.5 log reduction of Salmonella serovars and 2-5 log reduction in $E$. coli $0157: \mathrm{H} 7$, depending on the category of the product (cooked or shelf stable beef). It is also recommended that the process should include a heating step $\left(\sim 71^{\circ} \mathrm{C}\right)$. A similar study, but with drying occurring for only four days at a temperature of $25^{\circ} \mathrm{C}$, resulted in a reduction of $L$. monocytogenes up to 4.6 $\log$, and S. aureus up to $2.0 \log$ (Naidoo \& Lindsay, 2010b) from an initial final cell concentration of 7 log cfu. $\mathrm{mL}^{-1}$.

\section{Conclusion}

The biltong industry has become an economically important sector in the South African meat industry. Any contribution toward better understanding of biltong production could help to improve this sector. Gaps in research and knowledge show that there is no guidance for manufacturing biltong, with defined properties in terms of drying parameters and times, final moisture contents, $a_{w}$ and spice combinations. This leads to a variety of production processes and a wide spectrum of product characteristics that affect the sensory properties and microbial stability of biltong, while its shelf-life has not been assessed, even on a standard recipe. Factors that seem to influence the quality of biltong include meat quality, processing, drying parameters and time, and packaging. Drying parameters such as effective temperature, relative humidity, air velocity and time to dry the product efficiently and effectively constitute an area of research that would be valuable to biltong producers. These results could allow for scientific measures (moisture content, $\mathrm{a}_{\mathrm{w}}$, drying yields, etc.) to determine when the products could be removed from the dryers for good quality biltong. The addition of vinegar could be of major influence on the drying rate and shelf-life of biltong because of its effect on $\mathrm{pH}$. The use of preservatives in the industry and their consumer acceptance could also be investigated. Other factors include the effects of using fresh and frozen meat, as well as various muscles, on mass transfers during processing and the quality of biltong. While salting methods and conditions may vary, for example the use of tumbling, use of vacuums, tumbling time, storage before drying, and investigations of salt and vinegar penetration (homogeneity) would decide the conditions to use. Packaging is another area for which research is limited, and could involve a study of its impact on the stability and shelf-life of biltong. These areas of research also apply to the use of game in biltong production, with special attention to its lower fat content, higher $\mathrm{pH}$, and microbial load.

\section{Acknowledgements}

This work is based on the research supported by the South African Research Chairs Initiative of the Department of Science and Technology and National Research Foundation of South Africa. Opinions, findings and conclusions, and recommendation expressed in this material are those of the authors and the NRF does not accept liability.

\section{Authors' Contributions}


MJ, EA, PG, LCH conceptualized the review and its contents. MJ wrote most of the review. EA, PG, and LCH contributed to the final edition of the manuscript.

\section{Conflict of Interest Declaration}

None of the authors has any conflict of interest.

\section{References}

Aas, G.H., Skjerdal, O.T., Stoknes, I. \& Bjørkevoll, I., 2010. Effects of packaging method on salt-cured cod yield and quality during storage. J. Aquat. Food Prod. Technol.19, 149-161.

Ahmat, T., Barka, M., Aregbs, A-W. \& Bruneau, D., 2015. Convective drying kinetics of fresh beef: An experimental and modelling approach. J. Food Process. Preserv. 39, 2581-2595.

Attwell, E., 2003. Biltong wakes up. Food Rev. 30(2), 11, 13.

Asefa, D.T., Gjerde, R.O., Sidhu, M.S., Langsrud, S., Kure, C.F., Nesbakken, T. \& Skaar, I., 2009. Moulds contaminants on Norwegian dry-cured meat products. Int. J. Food Microbiol. 128, 435-439.

Bellagha, S., Sahli, A., Farhat, A., Kechaou, N. \& Glenza, A., 2007. Studies on salting and drying of sardine (Sardinella aurita): Experimental kinetics and modelling. J. Food Eng. 78, 947-952.

Betts, G.D. \& Everis, L.K., 2008. Hurdle techniques. In: Food biodeterioration and preservation. Edited by G.S. Tucker. Blackwell, Oxford. pp. 193-208.

Burfoot, D., Everis, L., Mulvey, L., Wood, A. \& Campden, R.B., 2010. Literature review of microbiological hazards associated with biltong and similar dried meat products. Food Standard Agency, London, $87 \mathrm{pp}$.

Burnham, G.M., Hanson, D.J., Koschick, C.M. \& Ingham, S.C., 2008. Death of Salmonella serovars, Escherichia coli 0157:H7, Staphylococcus aureus and Listeria monocytogenes during the drying of meat: A case study using biltong and droëwors. J. Food Safety. 28(2), 198-209.

Carr, M.A., Miller, M.F., Daniel, D.R., Yarbbrough, C.E., Petrosky, J.D. \& Thompson L.D., 1997. Evaluation of the physical, chemical and sensory properties of jerky processed from emu, beef and turkey. J. Food Quality 20, 419425.

Chabbouh, M., Hajji, W., Ahmed, S.B.H., Farhat, A., Bellagha, S. \& Sahli, A., 2011. Combined effects of osmotic dehydration and convective air drying on kaddid meats: Kinetics and quality. Dry. Technol. 29(13), 1571-1579.

Cheng, Q. \& Sun, D.-W., 2008. Factors affecting the water holding capacity of red meat products: a review of recent research advances. Crit. Rev. Food Sci. 48, 137-159.

Clemente, G., Bon, J., Sanjuán, N. \& Mulet, A., 2009. Determination of shrinkage function for pork meat drying. Dry. Technol. 27(1), 143-148.

Comaposada Beringues, J., 1999. Sorption isotherms and water diffusivity in muscles of pork ham at different $\mathrm{NaCl}$ contents. MSc thesis. Polytechnic University of Catalonia, Barcelona. http://hdl.handle.net/10803/6675.Coetzee, R. 1977. Spys en drank: Die oorsprong van die Suid-Afrikaanse eetkultuur. C. Struik, Kaapstad, South Africa.

Cook, P.E., 1995. Fungal ripened meats and meat products. In: Fermented meats. Edited by G. Campbell-Platt, \& P.E. Cook, Blackie Academic \& Professional, London. 110 pp.

CSIR, 2001. Investigations on the preparations of biltong. CSIR Food Biological and Chemical Technologies, Pretoria.

Day, B.P.F., 2008. Modified atmosphere packaging. In: Food biodeterioration and preservation. Edited by G.S. Tucker, Blackwell, Oxford. pp. 165-192.

Doe, P.E., Hashmi, R., Poulter, R.G. \& Olley, J., 1982. Isohalic sorption isotherms. I. Determination for dried salted cod (Gadus morhua). J. Food Technol. 17, 125-134.

Duan, Z., Jiang, L., Wang, J., Yu, X. \& Wang, T., 2011. Drying and quality characteristics of tilapia fish fillets dried with hot air-microwave heating. Food Bioprod. Process. 89, 472-476.

Dzimba, F.E.J.M., José de Assis, F.F. \& Walter, E.H. M., 2007. Testing the sensory acceptability of biltong formulated with different spices. Afr. J. Agr. Res. 2(11), 574-577.

Entani, E., Asai, M., Tsujihata, S., Tsukamoto, Y. \& Ohta, M., 1998. Antibacterial action of vinegar against foodborne pathogenic bacteria including Escherichia coli 0157:H7. J. Food Protect. 61(8), 953-959.

Fourie, H., 2015. Personal communication, 18 August 2015.

García-Esteban, M., Ansorena, D. \& Astiasarán, I., 2004. Comparison of modified atmosphere packaging and vacuum packaging for long period storage of dry-cured ham: Effects on colour, texture and microbiological quality. Meat Sci. 67(1), 57-63.

Guner, A., Gonulalan, Z. \& Dogruer, Y., 2008. Effect of tumbling and multi-needle injection of curing agents on quality characteristics of pastirma. Int. J. Food Sci. Technol.43, 123-129.

Hatamipour, M. S. \& Mowla, D., 2003. Correlations for shrinkage, density and diffusivity for drying of maize and green peas in a fluidized bed with energy carrier. J. Food Eng. 59(2-3), 221-227.

Heinz, G. \& Hautzinger, P., 2007. Meat processing technology for small- to medium-scale producers - meat drying. Food and Agriculture Organisation of the United Nations, Bangkok. www.fao.org/docrep/010/ai407e/ai407e18.htm. Accessed 5 May 2014.

Hii, C.L., Itam, C.E. \& Ong, S.P., 2014. Convective air drying of raw and cooked chicken meats. Dry. Technol. 32(11), 1304-1309.

Hoffman. L.C. \& Wiklund, E., 2006. Game and venison - meat for the modern consumer. Meat Sci. 74, 197-208.

Hoffman, L.C., Kroucamp, M. \& Manley, M., 2007. Meat quality characteristics of springbok (Antidorcas marsupialis), 1: Physical meat attributes as influenced by age, gender and production region. Meat Sci. 76, 755-761. 
Huang, T-C. \& Nip, W-C., 2001. Intermediate-moisture meats and dehydrated meat. In: Meat science and applications. Second edition. Edited by Y.H., Hui, W-C Nip, R.W, Rogers \& O.A. Young, Marcel Dekker, New York. pp. 429, 432-433.

Hui, Y.H. (ed.), 2012. Handbook of meat and meat processing. CRC Press, Florida.

Jessen, B., 1995. Starter cultures for meat fermentation. In: Fermented meats. Edited by G. Campbell-Platt \& P. E. Cook, Blackie Academic \& Professional, London. 142 pp.

Kucerova, I., Hubackova, A., Rohlik, B-A. \& Banout, J., 2015. Mathematical modelling of thin-layer solar drying of eland (Taurotragus oryx) jerky. Int. J. Food Eng. 11(2), 229-242.

Lara, J.A.F., Senigalia, S.W.B., Oliveira, T.C.R.M., Dutra, I.S., Pinto, M.F. \& Shimokomaki, M., 2003. Evaluation of survival of Staphylococcus aureus and Clostridium botulinum in charqui meats. Meat Sci. 609-613.

Leistner, L., 1987. Shelf stable products and intermediate moisture foods based on meat. In: Water activity: Theory and applications to food. Edited by L.B. Rockland, \& L.R. Beuchat. Marcel Dekker, New York. pp. 295-328.

Levine, P., Rose, B., Green, S., Ransom, G. \& Hill, W., 2001. Pathogen testing of ready-to-eat meat and poultry products collected at federally inspected establishments in the United States, 1990 to 1999. J. Food Protect. 64(8), 11881193.Markov, K., Pleadin, J., Bevardi, M., Vah, N., Sokolic-Mihalak, D. \& Frece, J., 2013. Natural occurrence of aflatoxin B-1, ochratoxin A and citrinin in Croatian fermented meat products. Food Control 2, 312-317.

Matsheka, M.I., Mpuchane, S., Gashe, B.A., Allotey, J., Khonga, E.B., Coetzee, S.H. \& Murindamombe, G., 2014. Microbial quality assessment and predominant microorganism of biltong produced in butcheries in Gaborone, Botswana. Food Nutr. Sci. 5, 1668-1678.

Mayor, L. \& Sereno, A.M., 2004. Modelling shrinkage during convective drying of food materials: A review. J. Food Eng. 61(3), 373-386.

Mhlambi, S.G., Naidoo, K. \& Lindsay, D., 2010. Enterotoxin-producing Staphylococcus strains associated with South African biltong at point of sale. J. Food Safety 30, 306-317.

Miller, M.F., Keeton, J.T., Cross, H.R., Leu, R., Gomez, F. \& Wilson, J.J., 1988. Evaluation of the physical and sensory properties of jerky processed from beef heart and tongue. J. Food Quality 11, 63-70.

Mulet, A., García-Reverter, J., Bon, J. \& Berna, A., 2000. Effect of shape on potato and cauliflower shrinkage during drying. Dry. Technol. 18(6), 1201-1219.

Mullen, M. \& McDowell, D., 2011.Modified atmosphere packaging. In: Food and beverage packaging technology, Second edition. Edited by R.Coles, \& M. Kirwan. Blackwell, Oxford. pp. 263-294.

Naidoo, K., 2010. The microbial ecology of biltong in South Africa during production and at point-of-sale. MSc thesis, University of the Witwatersrand, South Africa.

Naidoo, K. \& Lindsay, D., 2010a. Pathogens associated with biltong product and their in vitro survival of hurdles used during production. Food Prot. Trends. 30(9), 532-538.

Naidoo, K. \& Lindsay, D., 2010b. Survival of Listeria monocytogenes and enterotoxin producing Staphylococcus aureus and Staphylococcus pasteuri during two types of biltong manufacturing processes. Food Control 21, 1042-1050.

Naidoo, K. \& Lindsay D., 2010c. Potential cross-contamination of the ready-to-eat dried meat product, biltong. Brit. Food J. 112(4), 350-363.

Nel, M., 2016. Personal communication, 23 November 2016.

Nortje, K., Buys, E.M. \& Minnaar, A., 2005. Effect of $Y$-irradiation on the sensory quality of moist beef biltong. Meat Sci. $71,603-611$.

Nortje, K., Buys, E.M. \& Minnaar, A., 2006. Use of y-irradiation to reduce high levels of Staphylococcus aureus on casein-whey protein coated moist beef biltong. Food Microbiol. 23, 729-737.

Núñez, F., Rodríguez, M.M., Bermúdez, M.E., Córdoba, J.J. \& Asensio, M.A., 1996. Composition and toxigenic potential of the mould population on dry-cured lberian ham. Int. J. Food Microbiol. 32, 185-197.

Offer, G. \& Trinick, J., 1983. On the mechanism of water holding in meat the swelling and shrinking of myofibrils. Meat Sci. 8, 245-281.

Offer, G., Knight, P., Jeacocke, R., Almond, R., Cousins, T., Elsey, J., Parsons, N., Sharp, A., Starr, R. \& Purslow, P., 1989. The structural basis of the water-holding, appearance and toughness of meat and meat products. Food Microstruct. 8, 151-170.

Okos, M.R., Narsimhan, G., Singh, R.K. \& Weitnauer, A.C., 1992. Food dehydration. In: Handbook of food engineering. Edited by D.R. Heldman \& D.B. Lund, Marcel Dekker., New York. 440 pp.

Oliveira, H., Pedro, S., Nunes, M.L., Costa, R. \& Vaz-Pires, P., 2012. Processing of salted cod (Gadus spp.): A review. Compr. Rev. Food Sci. F. 11, 546-564.

Osterhoff, D.R. \& Leistner, L., 1984. South African beef biltong - another close look. J. S. Afr. Vet. Assoc. 55(4), 201202.

Palumbo, S.A., Komanowsky, M., Metzger, V. \& Smith, J.L., 1977. Kinetics of pepperoni drying. J. Food Sci. 42(4), 10291033.

Parra, V., Viguera, J., Sánchez, J., Peinado, J., Espárrago, F., Gutierrez, J.I. \& Andrés, A.I., 2010. Modified atmosphere packaging and vacuum packaging for long period chilled storage of dry-cured Iberian ham. Meat Sci. 84(4), 760768.

Petit, T., Caro, Y., Petit, A-S., Santchurn, S.J. \& Collignan, A., 2014. Physicochemical and microbiological characteristics of biltong, a traditional salted dried meat of South Africa. Meat Sci.96, 1313-1317.

Petrova, I., Bantle, M. \& Eikevik, T.M., 2015. Manufacture of dry-cured ham: A review. Part 2. Drying kinetics modelling and equipment. Eur. Food Res. Technol. 241(4), 447-458. 
Pintado, A.I.E., Monteiro, M.J.P., Talon, R., Leroy, S., Scislowski, V., Fliedel, G., Rakoto, D., Maraval, I., Costa, A.I.A., Silva, A.P., Pallet, D., Tomlins, K. \& Pintado, M.M.E., 2016. Consumer acceptance and sensory profiling of reengineered kitoza products. Food Chem. 198, 75-84.

Pinto, M.F., Ponsano, E.H.G., Franco, B.D.G.M. \& Shimokomaki, M., 2002. Charqui meats as fermented meat products: Role of bacteria for some sensorial properties development. Meat Sci. 61, 187-191.

Prior, B.A. \& Badenhorst, L., 1974. Incidence of Salmonellae in some meat products. S. Afr. Med. J. 48, $2532-2533$.

Robertson, G.L., 2006. Modified atmosphere packaging. In: Food packaging - principles and practice, Second edition. CRC Press, Florida.

SANS, 2011. South African National Standards (SANS) 885:2011. Processed meat products. SABS Standards Division. ISBN 978-0-626-26422-2.

Santchurn, S.J., Arnaud, E., Zakhia-Rozis, N. \& Collignan, A., 2012. Drying: Principles and applications. In: Handbook of meat and meat processing, Second edition. Edited by Y.H. Hui, CRC Press, Florida.

Saravacos, G.D. \& Kostaropoulos, A.E., 2002. Food dehydration equipment. In: Handbook for food processing equipment. Kluwer/Plenum, New York. 341 pp.

Serra, X., Ruiz-Ramirez, J., Arnau, J. \& Gou, P., 2005. Texture parameters of dry-cured ham m. biceps femoris samples dried at different levels as a function of water activity and water content. Meat Sci. 69, 249-254.

Shale, K. \& Malebo, N.J., 2011. Quantification and antibiotic susceptibility profiles of Staphylococcus aureus and Bacillus cereus strains isolated from biltong. J. Food Safety 31, 559-569.

Sonjak, S., Ličen, S.M., Frisvad, J.C. \& Gunde-Cimerman, N., 2011. The mycobiota of three dry-cured meat products from Slovenia. Food Microbiol. 28, 373-376.

Strydom, P.E. \& Zondagh, B., 2014. Biltong: A major South African ethnic meat product. In: Encyclopaedia of meat sciences, volume 1, second edition. Edited by W.K. Jensen, C. Dikeman \& M. Devine. Academic Press, Elsevier, London. pp. 515-517.

Taylor, M.B., 1976. Changes in microbial flora during biltong production. S. Afri. Food Rev. 3(2) 120-121, 123.

Toldrá, F. (ed.), 2015. Handbook of fermented meat and poultry, Second edition. John Wiley \& Sons, West Sussex.

Toldrá, F., Mora, L. \& Flores, M., 2010. Cooked ham. In: Handbook of meat processing. Edited by F.T oldrá, John Wiley \& Sons, West Sussex. pp 301-312.

Trujillo, F.J., Wiangkaew, C. \& Tuan Pham, Q., 2007. Drying modelling and water diffusivity in beef meat. J. Food Eng. $78,74-85$.

USDA (United States Department of Agriculture), Food Safety and Inspection Service (USDA-FSIS), 2014. FSIS Compliance Guideline For Meat and Poultry Jerky Produced by Small and Very Small Establishments. http://www.fsis.usda.gov/wps/wcm/connect/5fd4a01d-a381-4134-8b91-99617e56a90a/Compliance-GuidelineJerky-2014.pdf?MOD=AJPERES.

Van den Heever, L.W., 1970. Some public health aspects of biltong. J. S. Afr. Vet. Med. Assn. 41(4), $263-272$.

Van der Riet, W.B., 1976a. Studies on the mycoflora of biltong. S. Afri. Food Rev. 3 (February), 105, 107,109, 111.

Van der Riet, W.B., 1976b. Water sorption isotherms of beef biltong and their use in predicting critical moisture contents for biltong storage. S. Afri. Food Rev., 3 (December), 93-95.

Van der Riet, W.B., 1982. Biltong - a South African dried meat product. Fleischwirtschaft 62(8), 970, 972-973.

Van Tonder, H. \& Van Heerden, W., 1992. Make your own biltong and droëwors, Illustrated edition. Struik, Cape Town. pp. 9-19.

Van Wyk, M., 2007. The complete South African cookbook, Third Edition. Struik, Cape Town. pp. 107-108.

Wolter, H., Laing, E. \& Viljoen, B.C., 2000. Isolation and identification of yeasts associated with intermediate moisture meats. J. Food Technol. Biotechnol. 38(1), 69-75.

Xiong, Y.L., 2004. Muscle proteins. In: Proteins in food processing. Edited by R.Y. Yada, Woodhead, Cambridge, England. pp 100-122. 